MR. JUNIOR SMITH TORRES-ROMAN (Orcid ID : 0000-0001-5310-6077)

Article type : Original Article

Article category: Urological Oncology

\title{
Prostate Cancer Mortality rates in Peru and its geographic regions
}

J. Smith Torres-Roman ${ }^{1,2}$, Eloy F. Ruiz ${ }^{3}$, Jose Fabian Martinez-Herrera ${ }^{4}$, Sonia Faria Mendes Braga ${ }^{5}$, Luis Taxa ${ }^{6}$, Jorge Saldaña-Gallo ${ }^{1}$, Mariela R Pow-Sang ${ }^{7}$, Julio M. PowSang $^{8}$, Carlo La Vecchia ${ }^{9}$

\section{Authors' Affiliations}

1. Clinica de Urologia Avanzada UROZEN, Lima, Peru.

2. Facultad de Medicina Humana, Universidad Nacional San Luis Gonzaga, Ica, Peru.

3. CONEVID, Unidad de Conocimiento y Evidencia, Universidad Peruana Cayetano Heredia, Lima, Peru.

4. Cancer Center, Medical Center American British Cowdray, Mexico City, Mexico

5. Department of Social and Preventive Medicine, Faculty of Medicine, Universidade Federal de Minas Gerais (UFMG). Belo Horizonte, Brazil.

6. Instituto Nacional de Enfermedades Neoplasicas, Lima, Peru.

7. Department of Urology, Instituto Nacional de Enfermedades Neoplásicas, Lima, Peru.

8. Department of Genitourinary Oncology, Moffitt Cancer Center, Tampa, Florida.

9. Department of Clinical Sciences and Community Health, Universitá degli Studi di Milano 20133, Milan, Italy.

Mails

JST: jstorresroman@gmail.com

EFR: ruizeloyf@gmail.com

JFM: jfabianmh.med@hotmail.com

SFM: sonia.fm.braga@gmail.com

LT: Itaxa@inen.sld.pe

JSG: jsaldana@urozen.com

MRP: mrpowsang@hotmail.com

JMP: julio.powsang@moffitt.org

CL: carlo.lavecchia@unimi.it

This article has been accepted for publication and undergone full peer review but has not been through the copyediting, typesetting, pagination and proofreading process, which may lead to differences between this version and the Version of Record. Please cite this article as doi: 10.1111/bju.14578

This article is protected by copyright. All rights reserved. 


\section{Corresponding Author}

Junior Smith Torres Román

Av. Javier Prado Este 3028, San Borja

Phone: +5156993219508

Email: jstorresroman@gmail.com

Address: 15037

\section{ABSTRACT \\ Background}

Prostate cancer is the fifth most prevalent cause of cancer death in men worldwide. A recent report described the mortality rates for prostate cancer in Peru, but a comprehensive evaluation of variations in prostate cancer epidemiology by geographic areas has not been performed, yet. Our aim is to evaluate the mortality rates of prostate cancer, according to geographical areas in Peru, between 2005 and 2014.

\section{Methods}

Information was extracted from the Deceased Registry of the Peruvian Ministry of Health. We analysed age-standardized mortality rates (world population) per 100,000 men. Spatial autocorrelation was determined according to the Moran Index. In addition, we used Cluster Map to explore relations between departments.

\section{Results}

Mortality rates increased from 20.9 (2005-2009) to 24.1 (2010-2014) per 100,000 men, an increase of $15.2 \%$. According to regions, during the period 2010-2014, the coast had the highest mortality rate $(28.9 / 100,000)$ while the rainforest had the lowest $(7.43 / 100,000)$. In addition, there was an increase in mortality in the coast and a decline in the rainforest over the period 2005-2014. The departments with the highest mortality were Piura, Lambayeque, La Libertad, Callao, Lima, Ica, and Arequipa. Moreover, these departments (except Arequipa) showed increasing trends during the years under study. The departments with the lowest observed prostate cancer mortality rates were Loreto, Ucayali, and Madre de Dios. This study showed positive spatial autocorrelation (Moran's I: 0.30, $p=0.01$ ).

\section{Conclusion}

Mortality rates from prostate cancer in Peru continue to increase. These rates are higher in the coastal region compared to those from the highlands or rainforest.

This article is protected by copyright. All rights reserved. 


\section{Keywords: Prostatic neoplasms, Spatial clustering, Mortality, Peru.}

\section{BACKGROUND}

Prostate cancer is the second most frequently diagnosed neoplasm in men and the fifth cause of cancer death worldwide [1-3]. In 2012, it represented $15 \%$ of all new cases of cancer diagnosed in men [1]; and in 2013, it caused 4.8 million disability-adjusted life-years (DALYs) worldwide, of which 43\% were in low- and middle-income countries (LMICs) [4].

For most LMICs, data collection related to incidence and mortality of prostate cancer has limited validity [5]. In order to understand these patterns in Latin America, we conducted a literature search [6] regarding prostate cancer in the region. Between 2005 and 2009, mortality rates for Cuba were of 23.6 per 100,000 men and, between 2007 and 2009, Uruguay and Venezuela reported more than 18 deaths per 100,000 men. Overall, Latin America prostate cancer mortality at all ages has trended to increase [7].

In Peru, the incidence rates for prostate cancer were high in specific areas (Lima and Arequipa with 48.4 and 32.1 per 100,000 population, respectively) [8]. Moreover, for Metropolitan Lima, it was reported that the age-standardised mortality rate (ASMR) for prostate cancer increased from 11.4 (2004-2005) to 15.7 (2010-2012) per 100,000 population $[9,10]$. There are still no recent epidemiological studies focusing solely on prostate cancer in Peru and analysing it by regions.

The objective of this study is to provide the first epidemiological evidence regarding the mortality rates from prostate cancer in Peruvian men between 2005 to 2014, according to geographical location.

This article is protected by copyright. All rights reserved. 


\section{METHODS}

\section{Design and study setting}

We conducted a secondary data analysis on the Peruvian Ministry of Health's database regarding prostate cancer deaths (code C61 according to the International Classification of Diseases, 10th revision) [11] between 2005-2014.

These registries are based on the reports from hospitals that are distributed throughout the country and most of which are part of the health network of the Ministry of Health. Although they do not include information from other sources (such as social security insurance or private insurances), they collect information on cancers in all departments from the main provider of healthcare service (70\%) [12]. The cancer reporting system is limited by the scarcity of staff in public hospitals, high staff turnover, and the lack of supervision of data quality. These factors yield problems in data accuracy and completeness. For this reason, the calculation was made taking in consideration an underreporting of $40 \%$ estimated by the Peruvian Ministry of Health [13].

Peru is composed by 25 departments, distributed in three geographical regions: coast, highlands, and rainforest [14,15]. The coast has experienced significant and unplanned population growth in urbanised areas in low-altitude settings; the highlands are a highaltitude area, with both urban and rural population; and the rainforest is located throughout the Peruvian Amazon [14,15] (Figure 1).

Figure 1: Peru geographical zones by department. The asterisk denotes the department of Callao.

Source: National Statistics Institute [16]. 


\section{Statistical and spatial analysis}

We used the number of prostate cancer deaths and population data to calculate the agestandardized rates mortality (ASMR).

We calculated region specific mortality rates for each 5-year age group and calendar period and derived ASMR by the direct method, using the world standard population [17]. We estimated mortality rates per 100,000 men. As the denominator, we used the population in five-year age groups, provided by the National Statistics Institute [16]. We used the software R 3.4.1 [18] for the statistical analysis.

We used the GeoDA software package for the spatial analysis [19]. We mapped the spatial distribution of prostate cancer mortality rates to determine if geographic groups were evident. The spatial analysis was performed using Moran's I statistic. The map results in a spatial typology consisting of five categories of health regions: (i) 'high-high' (positive autocorrelation), (ii) 'low-high' (negative autocorrelation), (iii) 'low-low' (positive autocorrelation), (iv) 'high-low' (negative spatial autocorrelation), and (v) 'not significant' indicated that there was no spatial autocorrelation. The value of the Moran index varies between -1 and +1 , where negative values indicate a spatial conglomerate of territorial units with different values of analysis and positive values indicate a spatial conglomerate of territorial units with similar values of analysis. We used a reference distribution using 999 random permutations to indicate statistical significance.

\section{RESULTS}

The number of prostate cancer deaths in Peru during this period (2005-2014) was 13,522. Mortality rates from prostate cancer in Peru increased from 20.9 to 24.1 per 100,000 men between 2005-2009 and 2010-2014. This translates to a $15.2 \%$ increase (Table 1). Analysing by regions, the coastal region had the highest mortality with a range of 22.329.0/100,000 men when compared to the regions of the highlands (11.8-17.1/100,000 men) 
and rainforest (4.0-11.6/100,000 men) (Figure 2). Prostate cancer mortality rates increased by $16 \%$, and $15.6 \%$. in the coastal region and the highlands region respectively. In contrast, the mortality rates for the rainforest region decreased18.7\%. (Table 1).

The departments with the highest mortality were Piura, Lambayeque, La Libertad, Callao, Lima, Ica, and Arequipa (Figure 3). Of these, only Arequipa showed a decline of $22 \%$ in its mortality rate. Conversely, the other departments showed increasing trends: Piura (25.86 to $32.82 / 100,000$ men with a percentage increase of $18.8 \%$ ), Lambayeque (31.33 to $41.76 / 100,000$ men with a percentage increase of $11.6 \%)$, La Libertad (27.71 to $34.07 / 100,000$ men with a percentage increase of $18.3 \%)$, Callao $(19.70$ to $40.11 / 100,000$ men with a percentage increase of $22.1 \%$ ), Lima (22.62 to $28.82 / 100,000$ men a with a percentage increase of $22.5 \%$ ), and Ica (33.52 to $36.47 / 100,000$ men with a percentage increase of $24.1 \%$ ). The departments in the rainforest showed large increases in trends, mainly in Madre de Dios (2.18 to $17.74 / 100,000$ men with a percentage increase of $182 \%$ ) and Pasco (8.43 to 27.40/100,000 men with a percentage increase of 129.5\%) (Table 1 and Figure 4).

Concerning the spatial analysis and clustering, the mortality rates from 2005 to 2014 showed a positive spatial autocorrelation and significant clustering (Moran's I: $0.30, p=0.01$ ). The departments with the lowest observed prostate cancer mortality rates were located in the Peruvian North-East (Loreto, Ucayali, and Madre de Dios) as shown in Figure 5.

This article is protected by copyright. All rights reserved. 
Table 1. Age-standardized (world population) mortality rates per 100,000 men from prostate cancer at all ages in Peruvian geographic areas around 2005-2009 and 20102014, and corresponding change in rates.

\begin{tabular}{|c|c|c|c|}
\hline & 2005-2009 & 2010-2014 & $\begin{array}{l}\% \text { change }(2014- \\
2010 / 2005-2009)\end{array}$ \\
\hline Peru & 20.89 & 24.07 & 15.2 \\
\hline Coast & 24.96 & 28.94 & 16.0 \\
\hline Highlands & 13.73 & 15.87 & 15.6 \\
\hline Rainforest & 9.14 & 7.43 & -18.7 \\
\hline Amazonas & 6.18 & 6.45 & 4.42 \\
\hline Ancash & 13.13 & 17.47 & 33.1 \\
\hline Apurimac & 10.40 & 13.36 & 28.5 \\
\hline Arequipa & 29.49 & 23.01 & -22.0 \\
\hline Ayacucho & 11.97 & 14.39 & 20.3 \\
\hline Cajamarca & 14.68 & 15.42 & 5.0 \\
\hline Callao & 29.31 & 35.77 & 22.1 \\
\hline Cusco & 10.42 & 6.83 & -34.5 \\
\hline Huancavelica & 11.78 & 21.53 & 82.8 \\
\hline Huanuco & 20.50 & 27.27 & 33.0 \\
\hline Ica & 26.95 & 33.46 & 24.1 \\
\hline Junin & 15.89 & 19.06 & 19.9 \\
\hline La Libertad & 25.82 & 30.53 & 18.3 \\
\hline Lambayeque & 30.48 & 34.02 & 11.6 \\
\hline Lima & 23.92 & 29.29 & 22.5 \\
\hline Loreto & 7.30 & 3.42 & -53.1 \\
\hline Madre de Dios & 7.97 & 22.47 & 182.0 \\
\hline Moquegua & 22.13 & 16.57 & -25.1 \\
\hline Pasco & 8.85 & 20.31 & 129.5 \\
\hline Piura & 27.56 & 32.75 & 18.8 \\
\hline Puno & 13.56 & 15.08 & 11.3 \\
\hline San Martin & 10.10 & 8.97 & -11.3 \\
\hline Tacna & 16.72 & 21.67 & 29.7 \\
\hline Tumbes & 26.52 & 17.05 & -35.7 \\
\hline Ucayali & 14.20 & 10.28 & -27.7 \\
\hline
\end{tabular}

This article is protected by copyright. All rights reserved. 


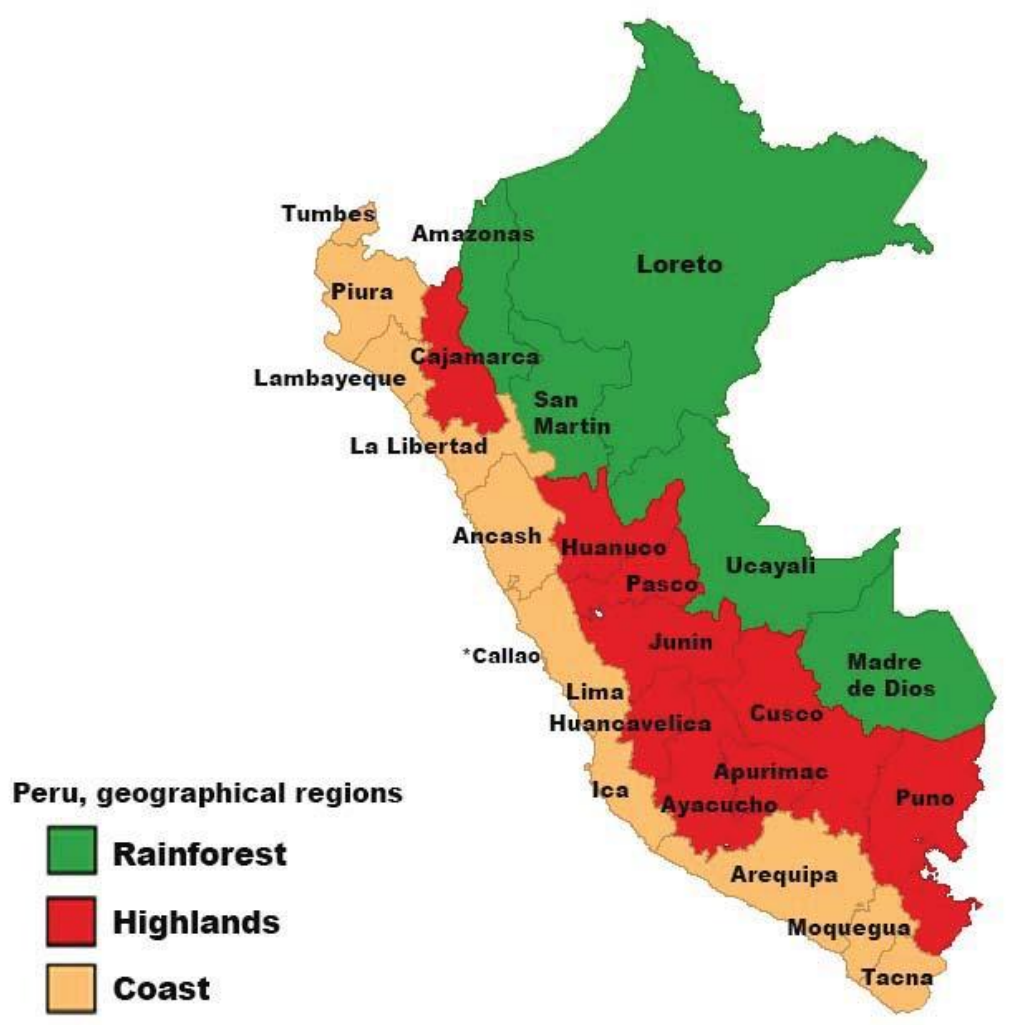

This article is protected by copyright. All rights reserved. 
Figure 2. Age-standardised mortality rates (per 100000 men) for prostate cancer in Peru and its regions from 2005 to 2014.

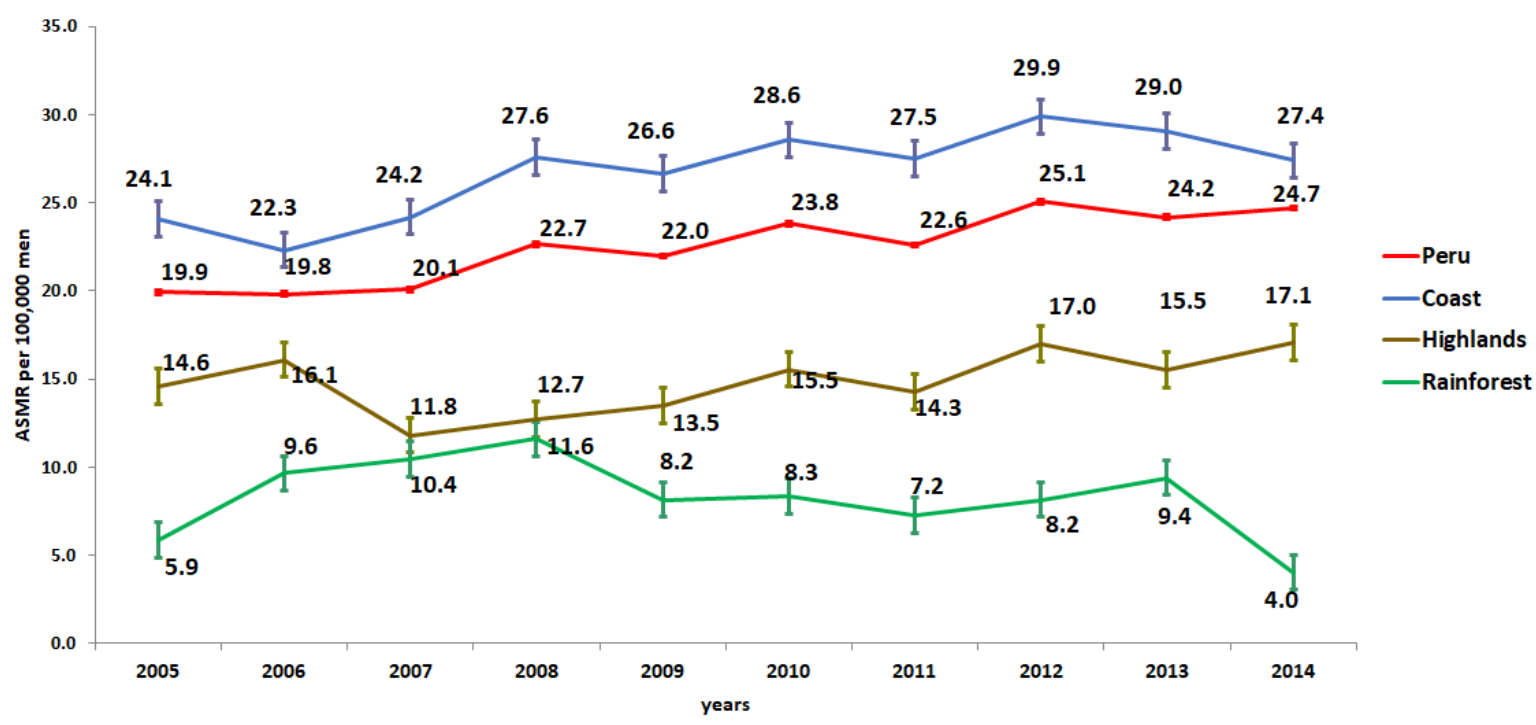

This article is protected by copyright. All rights reserved. 
Figure 3. Age-standardised mortality rates (per 100000 men) for prostate cancer by departments in Peru from 2005 to 2014.
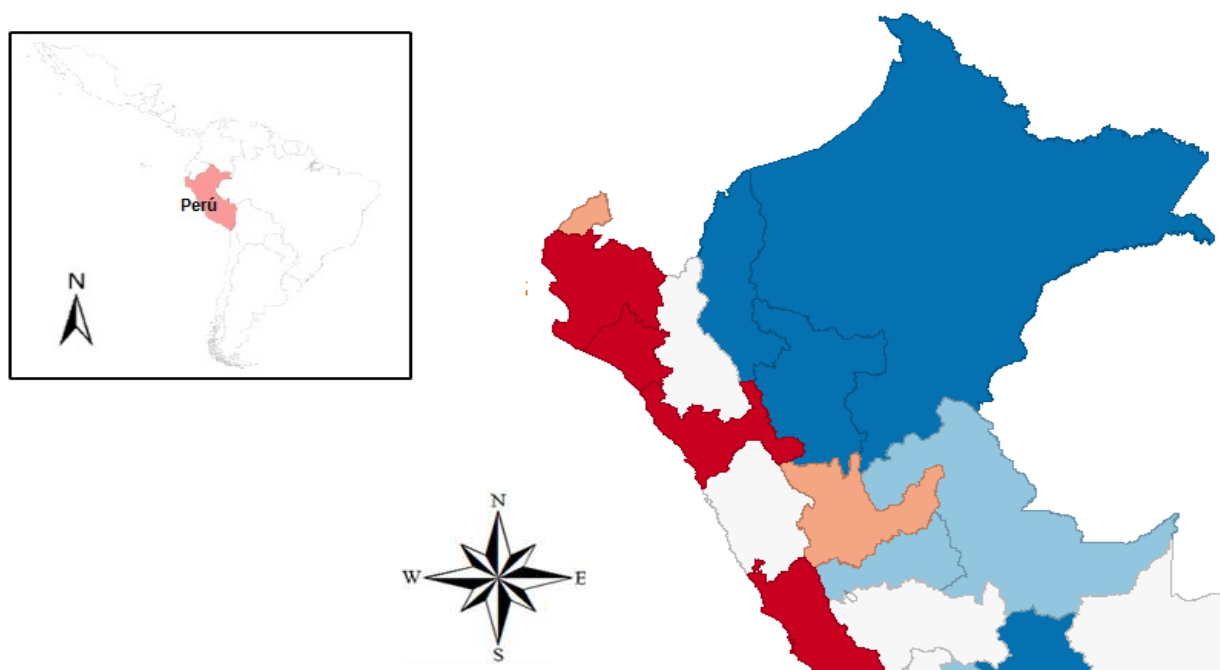

ASMR X 100,000 men
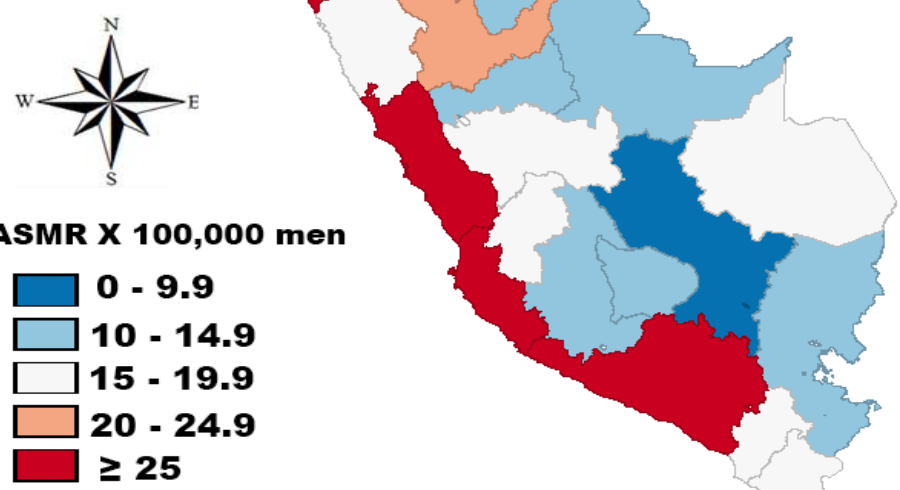

This article is protected by copyright. All rights reserved. 
Figure 4. Trends of age-standardized (world population) mortality rates per 100,000 men from prostate cancer in all departments of Peru.

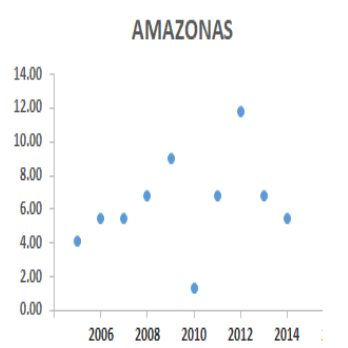

CAJAMARCA

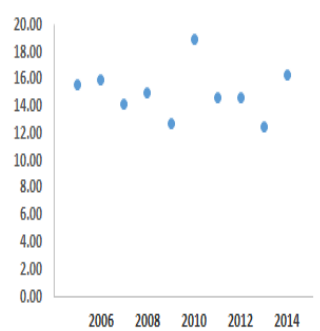

ICA

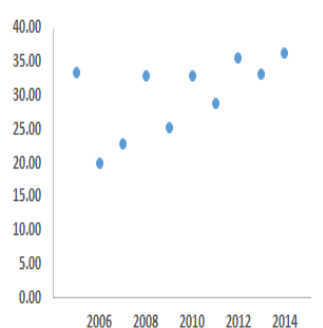

LORETO

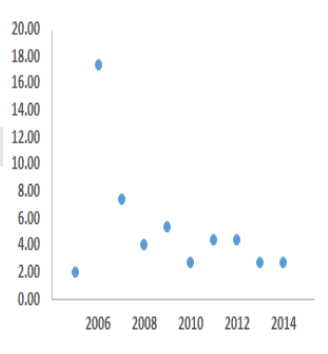

PUNO

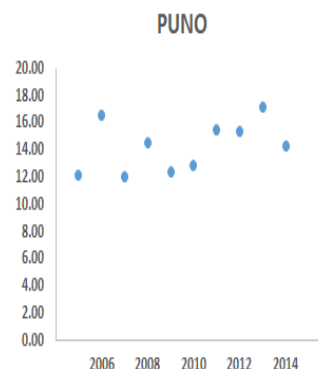

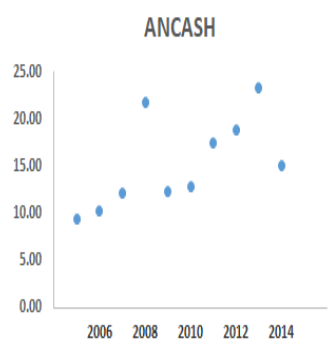

CALLAO

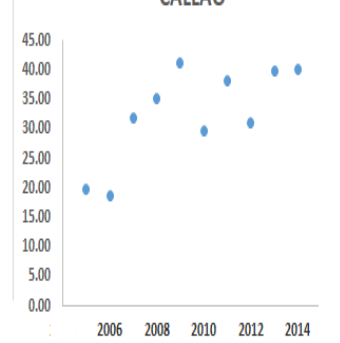

JUNIN

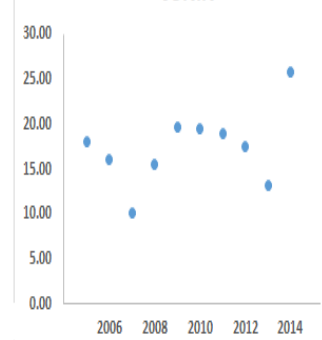

MADREDEDIOS

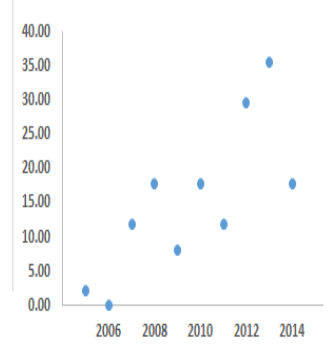

SAN MARTIN

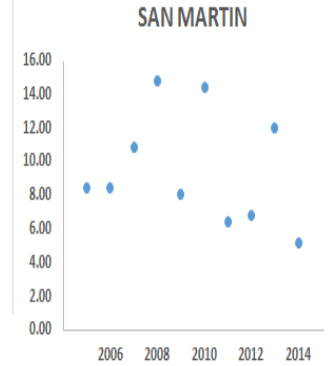

APURIMAC

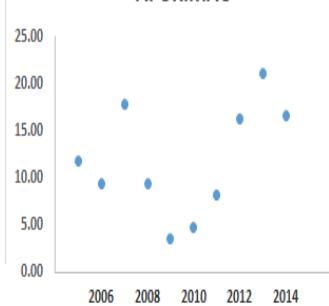

Cusco

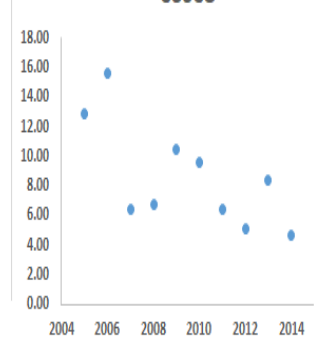

LALIBERTAD

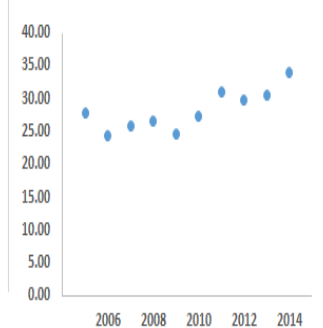

MOQUEGUA
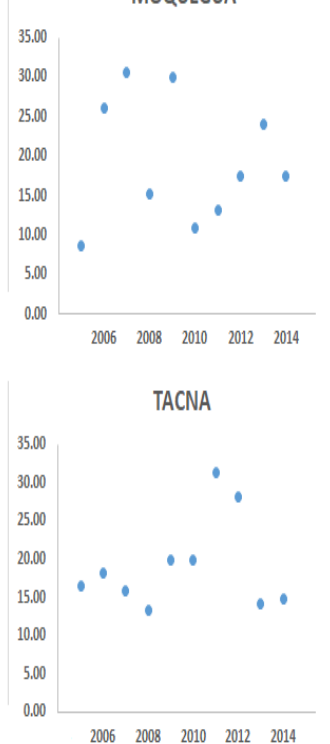

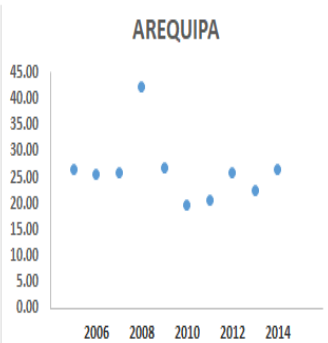

HUANCAVELICA

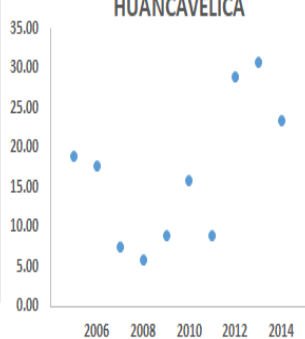

LAMBAYEQUE

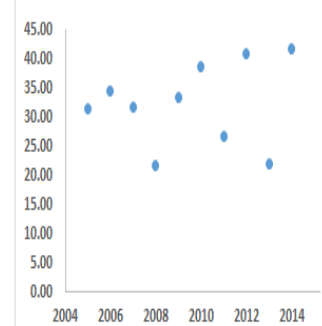

PASCO
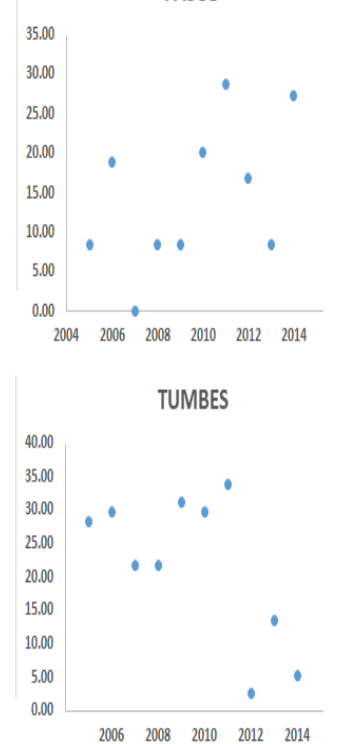

AYACUCHO

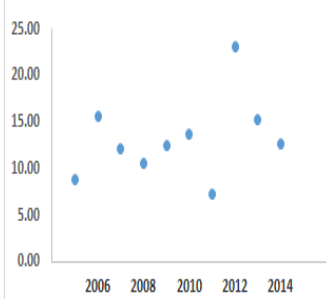

HUANUCO

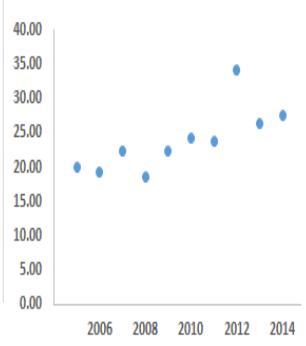

LIMA

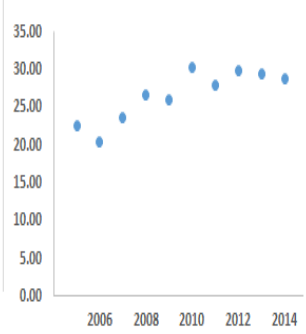

PIURA

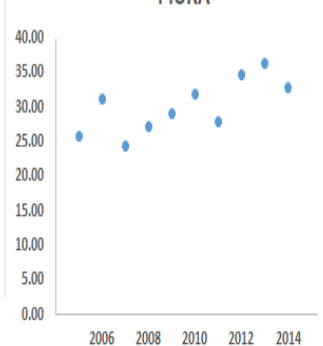

$\begin{array}{lllll}2006 & 2008 & 2010 & 2012 & 2014\end{array}$

UCAYALI

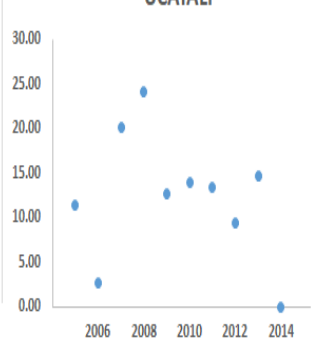

This article is protected by copyright. All rights reserved. 
Figure 5. Spatial cluster map of prostate cancer mortality rates for the period 20052014.

Bottom graphs show the results of local cluster analysis: $p$-values and the corresponding set of significant outliers and clusters for a $<0.05$ significance level.
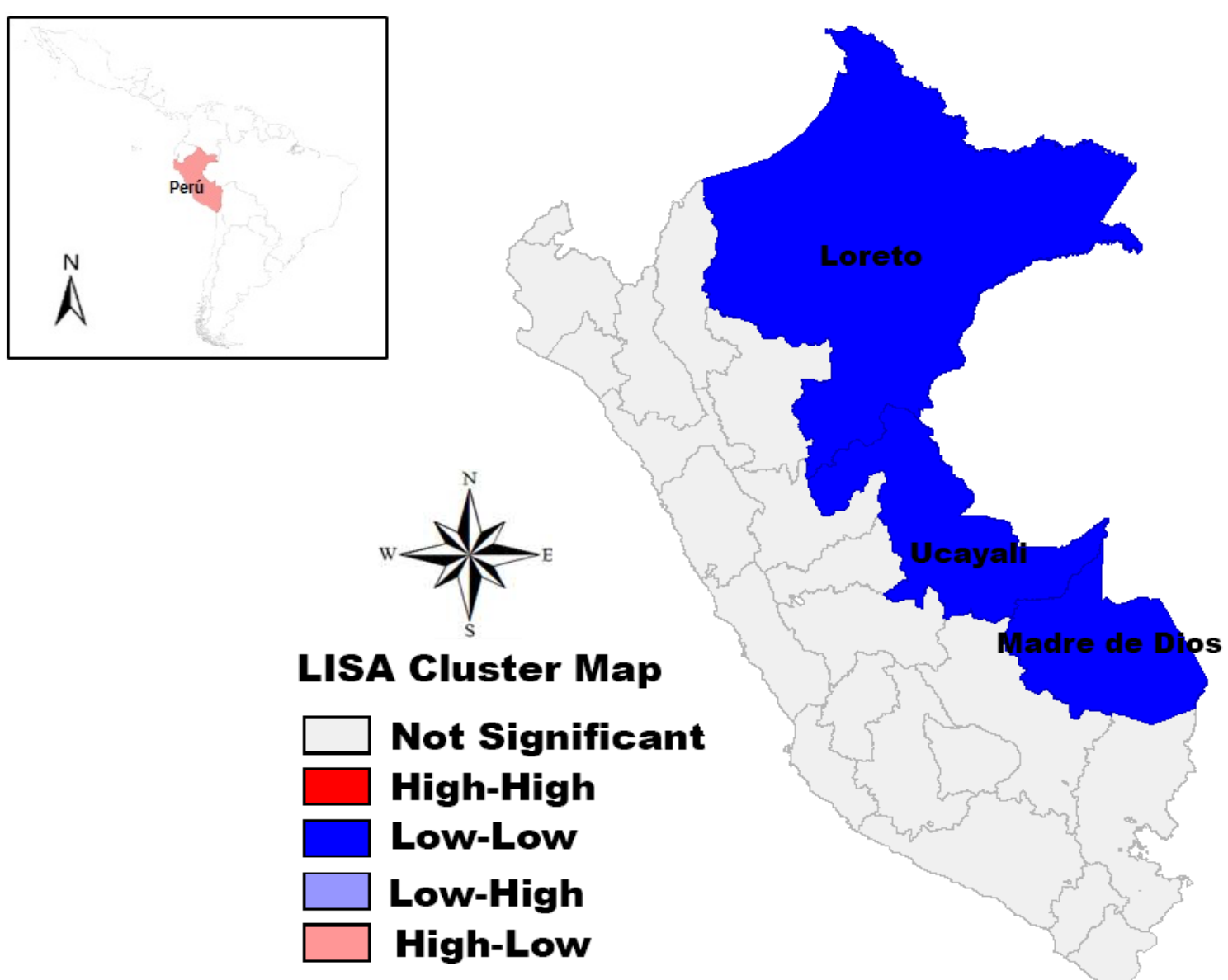

Moran's I: $\mathbf{0 . 3 0}$

$\mathbf{p}=0.01$ 


\section{DISCUSSION}

Mortality rates from prostate cancer in Peru continue to increase. We calculated, between $2005-2014$, an average rate of $22.5 / 100,000$ men and a percent increase of $15.2 \%$. A study by Sierra et al. [3], indicated that the mortality rate of prostate cancer was one of the two leading causes of cancer deaths in males in Central and South America, except in Chile, Argentina, Colombia, and El Salvador where it ranked third. In Belize (between 2003-2007), the highest rate reached 28.9 per 100,000 men; in Uruguay (between 2005-2007) it was of 21.8; and in Cuba (between 2004-2007) it was 24.1 per 100,000 men. The lowest rates were in Peru (between 2001-2005), Nicaragua (between 2003-2007), and El Salvador (between 1999-2003) with a range of 6.8-9.7 deaths per 100,000 men.

According to the National Household Survey, approximately $30 \%$ of the Peruvian population still does not have a health insurance [20,21]. The Peruvian health system is poorly organized with many disparities existing between healthcare providers' system [12], Preventive health policies have not been properly adopted by the Ministry of Health (there is no national screening program digital rectal examination and prostate-specific antigen levels for prostate cancer) [22].

According to regions, the highest mortality rates were observed in the coastal region (mainly in the departments of Piura, Lambayeque, La Libertad, Callao, Lima, Ica, and Arequipa) when compared to the highlands and the rainforest. This could be related to deficient reporting systems in the highlands and rainforest, as these areas are less developed with less accessible healthcare in these areas; However, the rates for both regions follow an ascending (highlands) and descending (rainforest) pattern over the years. Another explanation could be ethnic and racial differences, age, and overweight/obesity status in the coastal region. Regarding race, black men show a higher prostate cancer mortality rate [23] even adjusting with other cofactors like education and income levels [24,25]. Even though Peru has a high degree of racial mixing, the coastal region has a strong African influence 
[26] that may explain those high rates. In addition, the risk of prostate cancer also increases with age $[27,28]$, and more than $70 \%$ of men have histologic evidence of prostate cancer by the time they are 80 years old [17]. Currently, elderly adults represent $10 \%$ of the Peruvian population [18] and there is a larger proportion of men above 65 years of age in the coastal region (9\%) compared to the other two regions (the highlands and the rainforest with around $7 \%$ ) [10]. Another risk factor is overweight/obesity [27,29], which is associated with an increased risk of mortality and recurrence from prostate cancer [30]. Since the coastal region shows the highest obesity rates in adults [31] and children [15], this could also explain their higher mortality rate.

The coastal region has the main centres in oncology and the largest number of oncologytrained professionals, mainly in the department of Lima [8], including new cancer centres in the departments of La Libertad and Arequipa, which aim to help in the decentralization of cancer care [32]. However, this is not sufficient as most patients are diagnosed with advanced stages, leading to a poor prognosis [22,23]. Moreover, this region is considered the most densely populated with more than a third of the Peruvian population [34] and with the highest national Human Development Index (HDI) [35]. The latter demonstrates a directly proportional relationship with the burden of prostate cancer [36].

Regarding spatial analysis and clustering, the departments in north-eastern Peru (Loreto, Ucayali, and Madre de Dios) showed significantly lower mortality rates compared to their neighbouring departments. However, some departments, as Madre de Dios, have increased their mortality in the last years.

Due to the lack of adequate services for the diagnosis and treatment of cancer, Peru is currently in the process of creating new cancer centres in the coast region and rainforest [32,37], in addition to establishing oncology units in general hospitals. The goal is to decrease the mortality from prostate cancer and other neoplasms among Peruvians in the future. However, we would like to recommend the addition of more professionals trained in 
oncology, especially in the regions of the highlands and rainforest. Additionally, a comprehensive approach is needed to reduce the disparities in access to cancer care as well as the modification of the risk factors related to mortality for prostate cancer.

This study has limitations related to the use of secondary sources of information, including the possibility of having incorrect or incomplete data. Likewise, the data obtained and analysed in the present study did not allow us to compare by ethnicity or socioeconomic status, which would have provided a clearer overview about the risk from prostate cancer in Peruvian men. Nevertheless, this is the first effort to contribute to the literature on geographical differences in prostate cancer mortality in Peru. This information should help in the creation of health policies aimed at the population at risk and in the improvement of data collection systems.

In conclusion, mortality rates from prostate cancer in Peru are still increasing. The mortality rates were higher in the coastal region. Conversely, they were lower in the highlands and rainforest. These related geographical differences in mortality could be a reflection of race/genetics and other well-established and modifiable risk factors, including obesity, the lack of a decentralized health system and disparities in access to cancer care and incomplete reporting between regions. They may also reflect different validity of diagnosis and registration, which are difficult to evaluate, but are unlikely to totally explain the observed large variation in mortality rates.

This article is protected by copyright. All rights reserved. 


\section{List of abbreviations}

DALYs: disability-adjusted life-years

LMICs: Low- and middle-income countries

HDI: Human Development Index

ASMR: Age-standardized mortality rate

\section{Declarations}

\section{Ethics approval and consent to participate}

Ethical approval and consent of the participant were not necessary since this study involved the use of a previously published secondary database.

\section{Consent for publication}

Not applicable

\section{Competing interests}

The author(s) declare that they have no competing interests.

\section{Funding}

Self-funded.

\section{Authors' contributions}

JST, JSG conceived the research idea and collected the data. JST, JFM, EFR, LT perform the first version of the manuscript. All authors designed the study. JST, SFM performed the statistical and spatial analyses. MRP, JMP, and CLV provided the critical review of the manuscript. All authors drafted the manuscript and approved the final version. 


\section{REFERENCES}

1. Ferlay J, Soerjomataram I, Dikshit R, et al. Cancer incidence and mortality worldwide: sources, methods and major patterns in GLOBOCAN 2012. Int J Cancer 2015; 136: E359E86.

2. Torre LA, Bray F, Siegel RL, Ferlay J, Lortet-Tieulent J, Jemal A. Global cancer statistics, 2012. CA Cancer J Clin 2015; 65: 87-108.

3. Sierra MS, Soerjomataram I, Forman D. Prostate cancer burden in Central and South America. Cancer Epidemiol 2016; 44: S131-S40.

4. Fitzmaurice C, Dicker D, Pain A, et al. The global burden of cancer 2013. JAMA Oncol 2015; 1: 505-27.

5. Tourinho-Barbosa RR, Pompeo ACL, Glina S. Prostate cancer in Brazil and Latin America: epidemiology and screening. International Braz J Urol 2016; 42: 1081-90.

6. Ruiz EF, Proaño A, Proaño D, Torres-Román JS, Miranda JJ. The Latin America and the Caribbean search strategy proposal. Glob Health Promot 2016:1757975916661089.

7. Chatenoud L, Bertuccio P, Bosetti C, et al. Trends in mortality from major cancers in the Americas: 1980-2010. Ann Oncol 2014; 25: 1843-53.

8. Piñeros $\mathrm{M}$, Ramos $\mathrm{W}$, Antoni $\mathrm{S}$, et al. Cancer patterns, trends, and transitions in Peru: a regional perspective. Lancet Oncol 2017; 18: e573-e86.

9. Ministerio de Salud. Instituto Nacional de Enfermedades Neoplásicas. Registro de Cáncer de Lima Metropolitana 2004-2005.Vol IV, 2013.

10. Ministerio de Salud. Instituto Nacional de Enfermedades Neoplásicas. Registro de Cáncer de Lima Metropolitana 2010-2012.Vol V, 2016.

11. World Health Organization. International Classification of Disease and Related Health Problems: 10th Revision. Geneva: World Health Organization; 1992.

12. Málaga G, Romero ZO, Málaga AS, Cuba-Fuentes S. Shared decision making and the promise of a respectful and equitable healthcare system in Peru. Z Evid Fortbild Qual Gesundhwes 2017; 123: 81-4.

13. Perú, Ministerio de Salud. Análisis de la Situación del Cáncer en el Perú, 2013. Lima: Dirección General de Epidemiología, MINSA 2013 [Available from: http://www.dge.gob.pe/portal/docs/asis_cancer.pdf. 
14. Instituto Nacional de Estadística e Informática. Estado de la Población Peruana 2015. 2015 [cited 2017 January 20]. Available from: https://www.inei.gob.pe/media/MenuRecursivo/publicaciones_digitales/Est/Lib1251/Libro.pdf

15. Torres-Roman JS, Urrunaga-Pastor D, Avilez JL, Helguero-Santin LM, Malaga G. Geographic differences in overweight and obesity prevalence in Peruvian children, 20102015. BMC Public Health 2018; 18: 353.

16. Instituto Nacional de Estadistica e Informatica. Boletín de Análisis Demográfico № 37. Perú: Estimaciones y Proyecciones de Población por departamento, sexo y grupos quinquenales de edad, 1995-2025. [Available from: http://proyectos.inei.gob.pe/web/biblioineipub/bancopub/Est/Lib0846/index.htm.

17. World Health Organization. Age standardization of rates: a new WHO standard. Geneva, 2001. Available from: http://www.who.int/healthinfo/paper31.pdf

18. Team RC. R: A language and environment for statistical computing. Vienna, Austria: R Foundation for Statistical Computing. 2014.

19. Anselin L, Syabri I, Kho Y. GeoDa: an introduction to spatial data analysis. Geogr Anal 2006; 38: 5-22.

20. Torres-Roman JS, Arce-Huamani MÁ, Ruiz EF, Mejía CR. Actitudes frente a la autoexploración de mama en dos facultades de ciencias de la salud de Ica, Perú: un estudio piloto. Salud Publica Mex 2017; 59: 117-8.

21. Instituto Nacional de Estadistica e Informatica. Condiciones de vida en el Perú: Evolución 1997-2004. [updated Mayo 2006].

Available from: http://repositorio.minedu.gob.pe/bitstream/handle/123456789/316/174.\%20Condiciones\%20 de\%20vida\%20en\%20el\%20Per\%C3\%BA\%20Evoluci\%C3\%B3n\%2019972004.pdf? sequence $=1$ \&isAllowed $=y$

22. Pow-Sang M, Huamán MA. Challenges to early diagnosis of prostate cancer in Peru. Rev Peru Med Exp Salud Publica 2013; 30: 124-8.

23. Paschoalin EL, Martins AC, Pastorello M, et al. Racial influence on the prevalence of prostate carcinoma in Brazilian volunteers. Int Braz J Urol 2003; 29: 300-5.

24. Godley PA, Schenck AP, Amamoo MA, et al. Racial differences in mortality among 
Medicare recipients after treatment for localized prostate cancer. J Natl Cancer Inst 2003; 95: $1702-10$.

25. Cohen JH, Schoenbach VJ, Kaufman JS, et al. Racial differences in clinical progression among Medicare recipients after treatment for localized prostate cancer (United States). Cancer Causes Control 2006; 17: 803-11.

26. Wade P. Race in Latin America. A companion to Latin American anthropology. 2008:177-92.

27. Pernar CH, Ebot EM, Wilson KM, Mucci LA. The Epidemiology of Prostate Cancer. Cold Spring Harb Perspect Med 2018: a030361.

28. Di Sibio A, Abriata G, Forman D, Sierra MS. Female breast cancer in Central and South America. Cancer Epidemiol 2016; 44: S110-S20.

29. Golabek T, Bukowczan J, Chłosta P, Powroźnik J, Dobruch J, Borówka A. Obesity and prostate cancer incidence and mortality: a systematic review of prospective cohort studies. Urol Int 2014; 92: 7-14.

30. Cao Y, Ma J. Body-mass index, prostate cancer-specific mortality and biochemical recurrence: a systematic review and meta-analysis. Cancer Prev Res. 2011: 486-501.

31. Instituto Nacional de Estadistica e Informatica. Encuesta Nacional de Estadistica Sociodemografica. 2015.2 Available from: https://www.inei.gob.pe/media/MenuRecursivo/noticias/nota-de-prensa-n111-2016-inei.pdf

32. Salazar MR, Regalado-Rafael R, Navarro JM, Montanez DM, Abugattas JE, Vidaurre T. El Instituto Nacional de Enfermedades Neoplásicas en el control del cáncer en el Perú. Rev Peru Med Exp Salud Publica 2013; 30: 105-12.

33. Pow-Sang M, Destefano V, Astigueta JC, et al. Cáncer de próstata en Latinoamérica. Actas Urol Esp 2009; 33: 1057-61.

34. Instituto Nacional de Estadistica e Informatica. Informe Técnico: Evolución de la Pobreza Monetaria 2009-2014. Available from: https://www.inei.gob.pe/media/cifras_de_pobreza/informetecnico_pobreza2014.pdf

35. Instituto Nacional de Estadistica e Informatica. Perú: Síntesis Estadística 2015 [Available from: https://www.inei.gob.pe/media/MenuRecursivo/publicaciones_digitales/Est/Lib1292/libro.pdf 
36. Bray F, Jemal A, Grey N, Ferlay J, Forman D. Global cancer transitions according to the Human Development Index (2008-2030): a population-based study. Lancet Oncol 2012; 13: $790-801$.

37. Langevin SM, O'sullivan $\mathrm{MH}$, Valerio $\mathrm{JL}$, et al. Occupational asbestos exposure is associated with pharyngeal squamous cell carcinoma in men from the greater Boston area. Occup Environ Med 2013; 70: 858-63.

This article is protected by copyright. All rights reserved. 